\title{
Pharmacokinetics of sufentanil in normal children
}

Joanne Guay MD FRCPC, ${ }^{*} \ddagger$ Pierre Gaudreault MD FRCP, $\nmid \ddagger$ Alexander Tang MD FRCPC,* Benoit Goulet, $\ddagger$ France Varin PhD§
The pharmacokinetic variables of sufentanil were studied in 20 healthy children between two and eight years of age. The plasma concentrations of sufentanil were measured for up to $480 \mathrm{~min}$ afier administration of a bolus of sufentanil, $1-3 \mu \mathrm{g} \cdot \mathrm{kg}^{-1}$. The distribution half-life $\left(t_{1 / 2} \alpha\right)$ was $5.2 \pm 2.2$ (mean $\pm S D$ ) min and the elimination half life $\left(t_{1 / 2} \beta\right)$ was $97.0 \pm 42.0 \mathrm{~min}$. The volume of distriburion at steady state (Vdss) was $2.9 \pm 0.6 \mathrm{~L} \cdot \mathrm{kg}^{-1}$ and the clearance was $30.5 \pm 8.8 \mathrm{ml} \cdot \mathrm{kg}^{-1} \cdot \mathrm{min}^{-1}$. The Vdss was one and a half times greater than that reported in adults when expressed as a function of body weight but similar to that of adults when expressed as a function of body surface area. According to our results, the clearance of sufentanil in normal children between two and eight years of age is twice as rapid as that described in adults and adolescents. A greater clearance of sufentanil in children suggests that they would require relatively greater maintenance doses than adults.

La pharmacocinétique du sufentanil a été étudiée chez 20 enfants agés de deux à huil ans. Les concentrations plasmatiques ont pu être mesurées jusqu' à 480 min après l'administration d'un bolus de $l$ à $3 \mu g \cdot \mathrm{kg}^{-1}$ de sufentanil. La demi-vie de distribution $\left(t_{1 / 2} \alpha\right)$ était de $5,2 \pm 2,2$ min et la demi-vie d'élimination $\left(t_{12} \beta\right)$

\section{Key words:}

ANAESTHESIA: paediatric;

ANAESTHETICS-INTRAVENOUS: sufentanil;

PHARMACOKINETICS.

From the Departments of Anesthesiology* and Pediatrics, $\uparrow$ the Clinical Pharmacology and Toxicology Section. $\ddagger$ SainteJustine Hospital and the University of Montreal, and the Faculty of Pharmacy, \& University of Montrcal, Montreal, Quebec, Canada.

This study was supported in part by grants from Janssen Pharmaceutica Canada Lid. and from the Inter-Service Club Council of Montreal.

Prcsented at the $33^{\mathrm{c}}$ Congrès National d'Anesthésie et de Réanimation in Paris, September 1991.

Address correspondence to: Dr J Guay: Department of Anesthesiology, Sainte-Justine Hospital, 3175 Côte SteCatherine Road, Montreal, Quebec H3T 1C5 Canada.

Accepted for publication 30th August, 1991. était de 97,0 \pm 42,0 min. Le volume de distribution à l'état d'équilibre (Vdss) était $2,9 \pm 0,6 \mathrm{~L} \cdot \mathrm{kg}^{-1}$ et la clairance $30,5 \pm$ $8,8 \mathrm{ml} \cdot \mathrm{kg}^{-1} \cdot \mathrm{min}^{-1}$. Le Vdss est égal à environ une fois et demi celui de précédemment rapporté pour l'adulte lorsqu'il est exprimé en fonction du poids corporel et superposable à celui-ci lorsqu'il est exprimé en foncrion de la surface corporelle. D'après nos résultats la clairance du sufentanil chez l'enfant normal de deux à huit ans est environ deux fois celle décrite chez. l'adolescent et l'adulte. Une clairance augmentée suggère que les enfants nécessitent des doses d'entretien plus élevées.

Sufentanil is currently used in paediatric anaesthesia for cardiac and non-cardiac surgery. ${ }^{1-5}$ To date, in children less than ten years of age, the published sufentanil pharmacokinetic variables have been derived from patients with congenital heart disease. ${ }^{6-8}$ It has been shown that the pharmacokinetics of fentanyl in children with congenital cardiac disease may differ from those of normal children. ${ }^{9}$ In children with Fallot's tetralogy, the volume of distribution at steady-state (Vdss) was lower than that reported for normal children and there was a positive correlation between $\mathrm{PO}_{2}$ and the Vdss. ${ }^{9}$ It is possible that the pharmacokinetics of sufentanil obtained until now may not apply to normal children. The aim of this study was to describe the pharmacokinetic variables of sufentanil in normal children between two and eight years of age.

\section{Methods}

The protocol was approved by the hospital ethics committee and written informed consent was obtained for all patients. Twenty-five children between the ages of two and eight years, ASA physical status I and II, scheduled for elective anaesthesia and surgery, were included in this study. The patients had no history of cardiac, renal or hepatic disease and had received no medication in the week before anaesthesia apart from antibiotics. Only patients with a predicted blood loss during surgery of less than $5 \%$ of the estimated blood volume were included in the study. Each patient had fasted for at least eight hours and had received no premedication.

A standardized anaesthesia technique was used in all patients. After atropine $10 \mu \mathrm{g} \cdot \mathrm{kg}^{-1}$ and d-tubocurarine 50 $\mu \mathrm{g} \cdot \mathrm{kg}^{-1}$, anaesthesia was induced with thiopentone 5 to 7 
$\mathrm{mg} \cdot \mathrm{kg}^{-1}$ and succinylcholine $1.5 \mathrm{mg} \cdot \mathrm{kg}^{-1}$ was given to facilitate tracheal intubation after ventilation with $100 \%$ oxygen. Anaesthesia was maintained with $70 \%$ nitrous oxide, $30 \%$ oxygen and muscle relaxation was produced with pancuronium $0.07 \mathrm{mg} \cdot \mathrm{kg}^{-1}$. Sufentanil citrate was administered as a bolus of 1 to $3 \mu \mathrm{g} \cdot \mathrm{kg}^{-1}$ before surgical incision according to the estimated duration of surgery. Isoflurane was added to keep a mean blood pressure within $10 \%$ of preinduction values. Appropriate minute ventilation and fresh gas flows were calculated in order to maintain normocarbia using a coaxial circuit. Body temperature was kept between 36 and $38^{\circ} \mathrm{C}$. The maintenance fluid requirements were given as dextrose $2.5 \%$ in Ringer's lactate, and third space and surgical blood losses were replaced with Ringer's lactate. No other medication was given apart from prophylactic antibiotics when indicated. At the end of surgery, neuromuscular blockade was reversed with neostigmine $40 \mu \mathrm{g} \cdot \mathrm{kg}^{-1}$ and atropine $20 \mu \mathrm{g} \cdot \mathrm{kg}^{-1}$, and the tracheas were extubated after the resumption of spontaneous ventilation, adequate airway reflexes, and appropriate response to simple command.

Blood pressure and cardiac rate were recorded with an automated oscillometric blood pressure device (Dinamap $^{\circledR}$ ) on arrival in the operating room, after induction of anaesthesia, tracheal intubation, administration of sufentanil, surgical incision and every five minutes thereafter throughout surgery. Also noted were the times of induction of anaesthesia, administration of sufentanil, surgical incision, addition of isoflurane, the end of surgery and of anaesthesia. Furthermore the intervals between cessation of nitrous oxide and the following events: return of spontaneous ventilation, response to verbal command, and extubation were recorded. After extubation, a capillary blood gas was drawn and the patients were kept under observation in the recovery room for at least $90 \mathrm{~min}$. Incidence of vomiting in the recovery room and analgesic requirements during the first $24 \mathrm{hr}$ after surgery were also recorded. Supplemental analgesia in the recovery room or on the ward was administered at the discretion of the surgeon.

A heparinized venous catheter was installed on the dorsum of the hand or antecubital fossa on the side opposite to the site of drug injection. Three milliliters of blood were withdrawn for determination of sufentanil concentrations at the following times: $0,1,2,3,5,10,15$, $30,45,60,120,180,240,300,360,420$ and 480 min after sufentanil injection. These samples were sent to the laboratory on ice, centrifuged immediately and frozen at $-40^{\circ} \mathrm{C}$. Plasma concentrations of sufentanil were measured in duplicate by radioimmunoassay according to the technique described by Michiels et al. ${ }^{10}$ If these two values differed by more than $10 \%$, two new analyses were performed. In our laboratory, the limit of quantitation of

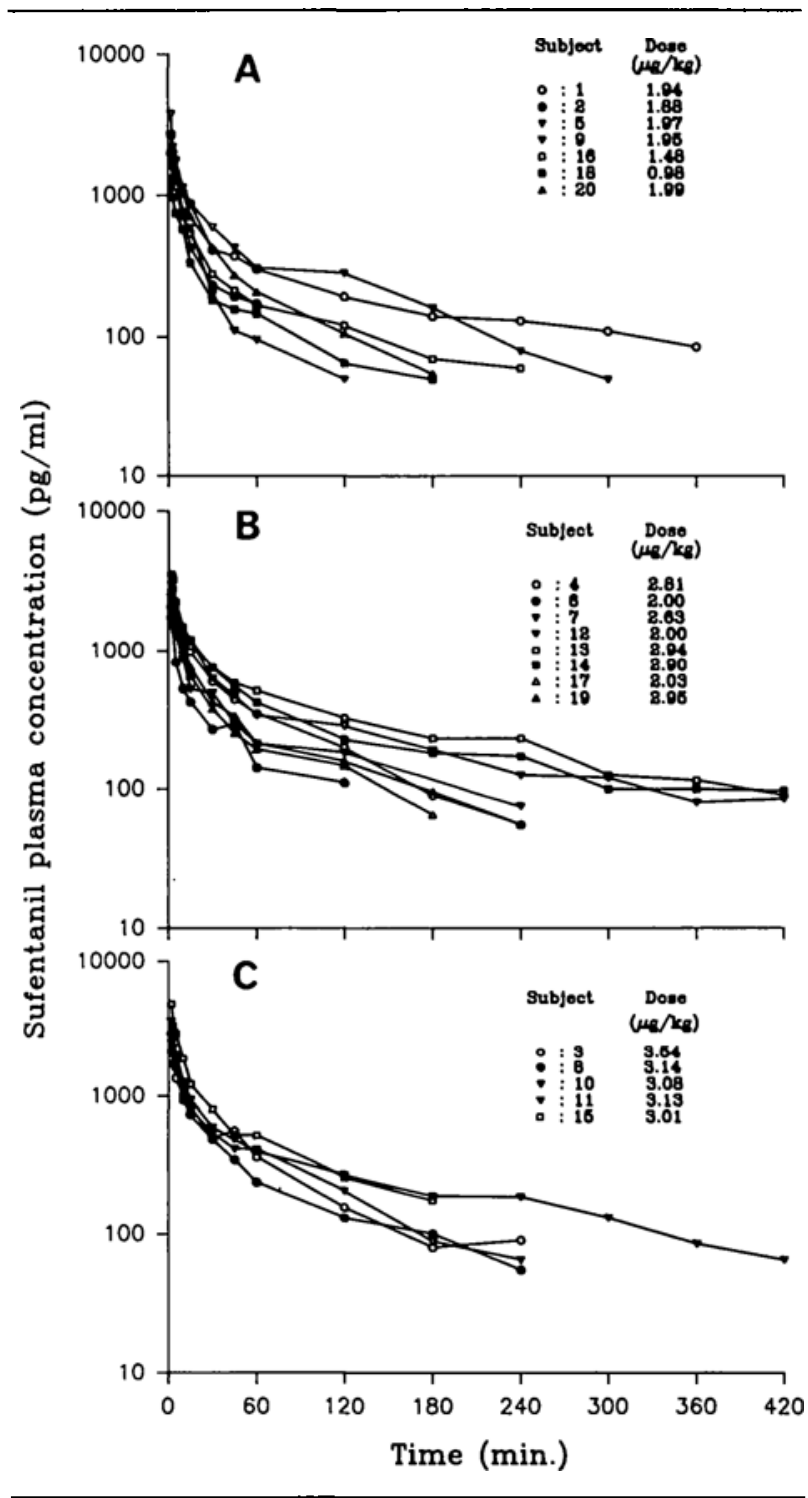

FIGURE Composite graphs of the measured plasina serum sufentanil concentrations versus time. The patients received the following doses: (a) 0.9 to $1.9 \mu \mathrm{g} \cdot \mathrm{kg}^{-1}$, (b) 2.0 to $2.9 \mu \mathrm{g} \cdot \mathrm{kg}^{-1}$ and (c) $>3.0 \mu \mathrm{g} \cdot \mathrm{kg}^{-1}$.

this technique was $50 \mathrm{pg} \cdot \mathrm{ml}^{-1}$. This assay was linear for concentrations from 50 to $4000 \mathrm{pg} \cdot \mathrm{ml}^{-1}$ with intra- and interassay coefficients of variation of 12 and $16 \%$ respectively at $300 \mathrm{pg} \cdot \mathrm{ml}^{-1}(n=4), 11$ and $13 \%$ at $600 \mathrm{pg} \cdot \mathrm{ml}^{-1}$ $(n=4), 8$ and $10 \%$ at $900 \mathrm{pg} \cdot \mathrm{ml}^{-1}(n=4)$.

The sufentanil plasma concentration-time profile showed a biexponential decay suggesting that a twocompartment open pharmacokinetic model was appropriate (Figure $a, b$ and $c$ ). The data were fitted to this model using the SIPHAR least-square fitting program (SIMED. Creteil, France) with an inverse weighting of the predicted squared $\left(1 / \mathrm{Y}^{2}\right)$ drug concentrations. The ability of a threecompartment model to describe the concentration-time 
TABLE I General data

\begin{tabular}{|c|c|c|c|c|c|c|c|}
\hline Patients & $\begin{array}{l}\text { Age } \\
\text { (yr/mth) }\end{array}$ & $\operatorname{Sex}$ & $\begin{array}{l}\text { Height } \\
(\mathrm{cm})\end{array}$ & $\begin{array}{l}\text { Weight } \\
(\mathrm{kg})\end{array}$ & $\begin{array}{l}\text { Surface } \\
\text { area } \\
\left(M^{2}\right)\end{array}$ & $\begin{array}{l}\text { Dose of } \\
\text { sufentanil } \\
\left(\mu g \cdot \mathrm{kg}^{-1}\right)\end{array}$ & Surgery \\
\hline 1 & $2 y \operatorname{lm}$ & $M$ & 89 & 12.1 & 0.43 & 1.94 & Tenotomy (foot) \\
\hline 2 & $2 y 7 m$ & $\mathbf{M}$ & 97 & 16.0 & 0.67 & 1.88 & Orchidopexy \\
\hline 3 & $2 y 8 m$ & $\mathbf{M}$ & 80 & 11.3 & 0.58 & 3.54 & Hypospadias \\
\hline 4 & $3 y 3 m$ & $\mathrm{~F}$ & 99 & 16.0 & 0.68 & 2.81 & Ureteroneocystostomy \\
\hline 5 & $3 y 10 m$ & $\mathbf{M}$ & 104 & 14.2 & 0.68 & 1.97 & Orchidopexy \\
\hline 6 & $4 y 7 m$ & $\mathbf{M}$ & 101 & 15.0 & 0.67 & 2.00 & Orchidopexy \\
\hline 7 & $4 y 7 m$ & $\mathbf{M}$ & 111 & 19.0 & 0.80 & 2.63 & Ureteroneocystostomy \\
\hline 8 & $4 y 10 \mathrm{~m}$ & $\mathrm{~F}$ & 107 & 17.5 & 0.76 & 3.14 & Pyeloplasty \\
\hline 9 & $5 y 3 \mathrm{~m}$ & M & 110 & 18.5 & 0.79 & 1.95 & Hypospadias \\
\hline 10 & $5 y 3 \mathrm{~m}$ & $\mathrm{~F}$ & 117 & 19.5 & 0.84 & 3.08 & Ureteroneocystostomy \\
\hline 11 & $5 y 4 m$ & $\mathbf{M}$ & 117 & 24.0 & 0.90 & 3.13 & Ear reconstruction \\
\hline 12 & Sy $4 m$ & $M$ & 123 & 24.0 & 0.94 & 2.00 & Bone grafi (thumb) \\
\hline 13 & 5y $5 \mathrm{~m}$ & $\mathbf{M}$ & 104 & 17.0 & 0.73 & 2.94 & Hypospadias \\
\hline 14 & $5 \mathrm{y} 9 \mathrm{~m}$ & $\mathbf{M}$ & 104 & 14.5 & 0.68 & 2.90 & Hypospadias \\
\hline 15 & $5 y 11 \mathrm{~m}$ & $\mathrm{~F}$ & 121 & 28.2 & 0.99 & 3.01 & Uretcroneocystostomy \\
\hline 16 & $5 \mathrm{y} 11 \mathrm{~m}$ & $\mathbf{M}$ & 113 & 25.0 & 0.93 & 1.48 & Repair of ureteral fistula \\
\hline 17 & $6 y 11 \mathrm{~m}$ & $\mathbf{F}$ & 136 & 29.6 & 1.11 & 2.03 & Cholecystectomy \\
\hline 18 & $7 y 6 m$ & F & 128 & 23.5 & 0.97 & 0.98 & Synovial cyst (knee) \\
\hline 19 & $7 y 6 m$ & F & 105 & 15.2 & 0.74 & 2.95 & Ureteroncocystostomy \\
\hline 20 & $8 y 9 m$ & $\mathrm{~F}$ & 126 & 22.6 & 0.94 & 1.99 & Femoral osteosynthesis \\
\hline Mean \pm SD & $5.2 \pm 1.7$ & $8 \mathrm{~F} / 12 \mathrm{M}$ & $109.5 \pm 13.6$ & $19.1 \pm 5.2$ & $0.79 \pm 0.16$ & $2.42 \pm 0.67$ & \\
\hline
\end{tabular}

profile adequately was compared and ruled out. Pharmacokinetic variables were derived according to standard formulae. " These included: fast distribution half-life $\left(t_{1 / 2} \alpha\right)$, elimination half-life $\left(t_{1 / 2} \beta\right)$, total body clearance $(\mathrm{Cl})$, apparent volume of distribution $\left(\mathrm{V}_{\mathrm{B}}\right)$, apparent volume of distribution at steady-state (Vdss) and apparent central volume of distribution (Vc). Volume of distribution at steady-state (Vdss) and clearance $(\mathrm{Cl})$ were also obtained using non-compartmental analysis and were similar to those obtained with the compartmental analysis, indicating the adequacy of the model.

\section{Results}

Of the 25 children evaluated, five boys were excluded from the study due to inadequate blood sampling. The descriptive data of the children who completed this study are listed in Table 1 . The patients received a mean dose of $2.41 \pm 0.65 \mu \mathrm{g} \cdot \mathrm{kg}^{-1}$ of sufentanil, i.e., median dose of 1.2 $\mu \mathrm{g} \cdot \mathrm{kg}^{-1}$ per hour of surgery $(0.7$ to 2.2$)$. After administration of sufentanil, the mean blood pressure decreased by $17.2 \%$ compared with the preoperative value and returned to baseline within five minutes of surgical incision. The mean maximum delivered concentration of isoflurane used was $0.7 \%$; this concentration was attained 80 min after surgical incision. After stopping nitrous oxide, the median time for resumption of spontaneous respiration was $11 \mathrm{~min}$ ( 2 to 23 ), for response to verbal stimulation 11.5 ( 2 to 38 ) min, and for extubation 11.5 ( 2 to 37 ) min. After extuba- tion (mean $31.6 \pm 11.3 \mathrm{~min}$ ), the mean capillary $\mathrm{pH}$ was $7.32 \pm 0.04$ and the mean capillary $\mathrm{PCO}_{2}$ was $47.6 \pm 7.8$ mmHg. Only two patients (10\%) required supplemental analgesia in the first hour after anaesthesia and five (25\%) did not require supplemental analgesia in the first postoperative $24 \mathrm{hr}$. One patient vomited during the $90 \mathrm{~min}$ of observation in the recovery room.

Sufentanil plasma concentration-time profiles obtained from all patients are represented in the Figure $a, b$ and $c$. Table II gives the pharmacokinetic data of the individual patients as well as the means and standard deviations for the group. The clearance of sufentanil did not vary with age or the dose administered (non-significant $r$ with linear regression analysis). Indeed, the clearance was $31.7 \pm 9.2$ $\mathrm{ml} \cdot \mathrm{kg}^{-1} \cdot \mathrm{min}^{-1}$ for the patients who received a sufentanil dose from 0.9 to $1.9 \mu \mathrm{g} \cdot \mathrm{kg}^{-1}$ (seven patients), $27.5 \pm 8.1$ $\mathrm{ml} \cdot \mathrm{kg}^{-1} \cdot \mathrm{min}^{-1}$ from 2.0 to $2.9 \mu \mathrm{g} \cdot \mathrm{kg}^{-1}$ (eight patients) and $33.5 \pm 9.8 \mathrm{ml} \cdot \mathrm{kg}^{-1} \cdot \mathrm{min}^{-1}>3.0 \mu \mathrm{g} \cdot \mathrm{kg}^{-1}$ (five patients).

\section{Discussion}

In this study, the distribution half-life $\left(\mathrm{T}_{1 / 2} \alpha\right)$ of sufentanil in children between two and eight years of age was approximately one-third that of adults $(5.2 \pm 2.2 \mathrm{~min}$ vs $17.7 \pm 2.6 \mathrm{~min}$ ) (Table III). ${ }^{12}$ The elimination half-life $\left(T_{1 / 2} \beta=97.0 \pm 42.0 \mathrm{~min}\right)$ was shorter than that reported for adults (164 $\pm 22 \mathrm{~min}$ ) and was slightly higher than that described for normal adolescents between ten and fifteen 
TABLE II Pharmacokinetic results

\begin{tabular}{|c|c|c|c|c|c|c|c|c|c|c|c|}
\hline Patients & $\begin{array}{l}t_{1 / \Omega^{\alpha}}^{\alpha} \\
\min \end{array}$ & $\begin{array}{l}t_{1 / 2} \beta \\
\min \end{array}$ & $\begin{array}{l}t_{p \text { rad }} \\
\min \end{array}$ & $\begin{array}{l}A \cup C_{\text {tend-x }} \\
\%\end{array}$ & $\begin{array}{l}\mathrm{Cl} \\
\mathrm{ml} \cdot \mathrm{kg}^{-1} \cdot \mathrm{min}^{-1}\end{array}$ & $\begin{array}{l}V c \\
L \cdot \mathrm{kg}^{-1}\end{array}$ & $\begin{array}{l}V B \\
L \cdot k g^{-I}\end{array}$ & $\begin{array}{l}V d s s \\
L \cdot k^{-1}\end{array}$ & $K_{10}$ & $K_{12}$ & $K_{21}$ \\
\hline 1 & 6.4 & 164.7 & 360 & 18.7 & 17.9 & 0.71 & 4.26 & 3.41 & 0.025 & 0.069 & 0.018 \\
\hline 2 & 3.4 & 64.5 & 60 & 34.9 & 40.6 & 0.53 & 3.85 & 2.58 & 0.079 & 0.110 & 0.028 \\
\hline 3 & 3.4 & 88.7 & 240 & 10.8 & 39.7 & 0.97 & 5.08 & 4.01 & 0.038 & 0.133 & 0.042 \\
\hline 4 & 7.3 & 66.0 & 240 & 6.3 & 34.0 & 1.18 & 3.24 & 2.65 & 0.030 & 0.042 & 0.034 \\
\hline 5 & 2.7 & 67.0 & 300 & 7.3 & 29.7 & 0.54 & 2.87 & 2.37 & 0.019 & 0.198 & 0.041 \\
\hline 6 & 4.1 & 83.5 & 120 & 19.6 & 29.7 & 0.83 & 3.57 & 3.04 & 0.036 & 0.102 & 0.039 \\
\hline 7 & 10.2 & 171.9 & 420 & 15.6 & 19.5 & 0.80 & 4.83 & 3.82 & 0.019 & 0.039 & 0.014 \\
\hline 8 & 4.4 & 73.7 & 240 & 8.4 & 44.9 & 0.99 & 4.78 & 3.65 & 0.045 & 0.088 & 0.033 \\
\hline 9 & 5.3 & 68.1 & 120 & 11.3 & 44.7 & 0.58 & 4.39 & 2.08 & 0.082 & 0.042 & 0.016 \\
\hline 10 & 4.0 & 66.2 & 240 & 7.3 & 36.1 & 0.92 & 3.36 & 2.95 & 0.040 & 0.099 & 0.045 \\
\hline 11 & 4.4 & 133.6 & 420 & 9.4 & 23.1 & 0.71 & 4.46 & 3.64 & 0.032 & 0.104 & 0.025 \\
\hline 12 & 2.9 & 86.1 & 240 & 12.3 & 26.5 & 0.48 & 3.29 & 2.63 & 0.055 & 0.160 & 0.035 \\
\hline 13 & 4.6 & 136.4 & 420 & 10.9 & 18.2 & 0.63 & 3.57 & 2.97 & 0.029 & 0.100 & 0.027 \\
\hline 14 & 10.9 & 204.9 & 420 & 14.6 & 19.1 & 0.86 & 5.64 & 3.95 & 0.022 & 0.035 & 0.010 \\
\hline 15 & 4.6 & 74.9 & 180 & 14.8 & 23.6 & 0.55 & 2.55 & 2.00 & 0.044 & 0.084 & 0.032 \\
\hline 16 & 3.9 & 99.0 & 240 & 15.0 & 25.9 & 0.47 & 3.69 & 2.69 & 0.054 & 0.106 & 0.023 \\
\hline 17 & 4.4 & 69.9 & 180 & 10.6 & 32.9 & 0.59 & 3.32 & 2.37 & 0.056 & 0.084 & 0.028 \\
\hline 18 & 5.2 & 81.1 & 180 & 18.7 & 28.0 & 0.71 & 3.27 & 2.54 & 0.040 & 0.073 & 0.028 \\
\hline 19 & 4.7 & 77.0 & 240 & 8.3 & 40.1 & 0.83 & 4.46 & 3.30 & 0.049 & 0.080 & 0.027 \\
\hline 20 & 7.2 & 62.0 & 180 & 8.7 & 35.2 & 0.89 & 3.15 & 2.23 & 0.041 & 0.040 & 0.027 \\
\hline Mean & 5.2 & 97.0 & 252 & 13.2 & 30.5 & 0.74 & 3.88 & 2.94 & 0.042 & 0.089 & 0.029 \\
\hline SD & 2.2 & 42.0 & 107 & 6.5 & 8.8 & 0.19 & 0.81 & 0.63 & 0.017 & 0.042 & 0.009 \\
\hline
\end{tabular}

$t_{\mathrm{end}}$ : time to reach limit of quantitation after the administration of sufentanil.

TABLE III Previously reported sufentanil pharmacokinctic data

\begin{tabular}{|c|c|c|c|c|c|c|c|c|}
\hline Author & Age & $\begin{array}{l}\text { Physical } \\
\text { status }\end{array}$ & $n$ & $\begin{array}{l}t_{1 / 2} \alpha \\
\min \end{array}$ & $\begin{array}{l}t_{1 / 2} \beta \\
\min \end{array}$ & $\begin{array}{l}\text { Clearance } \\
\mathrm{ml} \cdot \mathrm{kg}^{-1} \cdot \mathrm{min}^{-1}\end{array}$ & $\begin{array}{l}V B \\
\mathrm{~L} \cdot \mathrm{kg}^{-1}\end{array}$ & $\begin{array}{l}V d s s \\
L \cdot \mathrm{kg}^{-1}\end{array}$ \\
\hline \multirow[t]{2}{*}{ Greeley" } & $2-7 d$ & cardiopathy & 3 & 20.5 & 635 & 4.2 & & 2.7 \\
\hline & $20-28 d$ & cardiopathy & 3 & 8.8 & 217 & 17.3 & & 3.4 \\
\hline \multirow[t]{4}{*}{ Greeley $^{6}$} & 0-I mo & cardiopathy & 9 & $23.4 \pm 17.3$ & $737 \pm 346$ & $6.7 \pm 6.1$ & & $4.2 \pm 1.0$ \\
\hline & $\mathrm{I}-24 \mathrm{mo}$ & cardiopathy & 7 & $15.8 \pm 5.0$ & $214 \pm 41$ & $18.1 \pm 2.7$ & & $3.1 \pm 1.0$ \\
\hline & $2-12 \mathrm{yr}$ & cardiopathy & 7 & $19.6 \pm 6.0$ & $140 \pm 30$ & $16.9 \pm 2.2$ & & $2.7 \pm 0.5$ \\
\hline & $12-18 \mathrm{yr}$ & cardiopathy & 5 & $20.4 \pm 5.9$ & $209 \pm 23$ & $13.1 \pm 0.4$ & & $2.8 \pm 0.5$ \\
\hline \multirow[t]{2}{*}{ Davis 7} & $1-10 \mathrm{mo}$ & cardiopathy & 7 & & $53 \pm 15$ & $27.5 \pm 9.3$ & $1.6 \pm 0.5$ & \\
\hline & $10-36 \mathrm{mo}$ & cardiopathy & 6 & & $55 \pm 10$ & $18.1 \pm 10.7$ & $3.0 \pm 1.4$ & \\
\hline \multirow[t]{2}{*}{ Davis $^{13}$} & $10-15 \mathrm{yr}$ & $\begin{array}{l}\text { renal } \\
\text { insufficiency }\end{array}$ & 6 & $2.9 \pm 1.7$ & $89.7 \pm 15.7$ & $16.4 \pm 6.1$ & $1.7 \pm 0.6$ & \\
\hline & $10-15 \mathrm{yr}$ & normal & 6 & $2.5 \pm 0.7$ & $76.0 \pm 32.8$ & $12.8 \pm 12.0$ & $1.3 \pm 0.6$ & \\
\hline Bovill $^{12}$ & $26-64 \mathrm{yr}$ & normal & 10 & $17.7 \pm 2.6$ & $164 \pm 22$ & $12.7 \pm 0.8$ & $2.9 \pm 0.3$ & $1.7 \pm 0.2$ \\
\hline Guay* & $2-8$ yr & normal & 20) & $5.2 \pm 2.2$ & $97.0 \pm 42.0$ & $30.5 \pm 8.8$ & $3.9 \pm 0.8$ & $2.9 \pm 0.6$ \\
\hline
\end{tabular}

*Present study.

Mean $\pm S D$.

years of age $(76.0 \pm 32.8 \mathrm{~min}) .^{12.13}$ Although blood samples were collected for an eight-hour period in all patients, the limit of quantitation of the assay was often reached before the last sample (Table II). Estimation of the elimination half-life is highly dependent on duration of blood sampling and explains the high variability of the half-lives in our study.

The volume of distribution at steady state (Vdss) expressed as a function of body weight was about one and a half times greater than that previously described in adults $\left(2.9 \pm 0.6 \mathrm{~L} \cdot \mathrm{kg} \cdot{ }^{-1}\right.$ vs $\left.1.7 \pm 0.2 \mathrm{~L} \cdot \mathrm{kg}^{-1}\right) .^{12}$ When the Vdss was corrected for body surface area, however, the values were similiar to those of adults. Indeed, our patients had a mean Vdss of $56.2 \mathrm{~L}$ and a mean body surface area of $0.79 \mathrm{~m}^{-2}$, i.e., $71.2 \mathrm{~L} \cdot \mathrm{m}^{-2}$, compared with the data of Bovill, $124.7 \mathrm{~L}$ and $72.1 \mathrm{~L} \cdot \mathrm{m}^{-2}$ in adults. ${ }^{12}$ These data 
suggest that the initial dose of sufentanil calculated as a function of body weight will be approximately one and a half times that of adults, whereas the dose calculated as a function of body surface area will be identical to that of adults. The steady-state volume of distribution of sufentanil reported in children with cardiopathy seems to be identical to that of normal children $\left(2.7 \pm 0.5 \mathrm{~L} \cdot \mathrm{kg}^{-1} \cdot \mathrm{vs}\right.$ $\left.2.9 \pm 0.6 \mathrm{~L} \cdot \mathrm{kg}^{-1}\right)^{6}{ }^{6}$ These results differ from those obtained for fentanyl since the volume of distribution of fentanyl in children with cardiopathy was smaller than that of normal children. ${ }^{9}$ The greater lipid solubility of sufentanil and the subsequent increase in tissue diffusion probably accounts for this difference between the two drugs. ${ }^{14} \mathrm{~A}$ low cardiac output and/or a low pulmonary blood flow will affect the volume of distribution of fentanyl, to a greater extent than sufentanil. Therefore, these results suggest that in children with cardiopathy, the initial bolus dose of fentanyl but not of sufentanil should be reduced. ${ }^{9}$ This recommendation should be adjusted according to the haemodynamic response, since sufentanil may cause greater hypotension than fentanyl under certain circumstances.'

The plasma clearance with respect to body weight ( 30.5 $\left.\pm 8.8 \mathrm{ml} \cdot \mathrm{kg}^{-1} \cdot \mathrm{min}^{-1}\right)$ was twice as rapid as that reported for adolescents $\left(12.8 \pm 12.0 \mathrm{ml} \cdot \mathrm{kg}^{-1} \cdot \mathrm{min}^{-1}\right)$ and adults $\left(12.7 \pm 0.8 \mathrm{ml} \cdot \mathrm{kg}^{-1} \cdot \mathrm{min}^{-1}\right) \cdot{ }^{12.13}$ Several factors might have contributed to the difference between our results in children and those reported for adolescents and adults. Our results were obtained from venous blood samples as opposed to arterial blood samples in the Davis study. ${ }^{13}$ Blood concentrations measured from venous blood samples will be lower than those measured from arterial blood samples, at least shortly after the administration of the drug. The area under the curve obtained after a venous site of sampling will be smaller and hence the estimated clearance should be higher. ${ }^{15}$ However, for a very lipid soluble drug such as sufentanil the arterio-venous difference should decrease rapidly and the difference in the estimated clearance obtained from the two different sites of sampling should be small. This fast disappearance of the arterio-venous difference for sufentanil is confirmed by the fact that in our study the Vdss was found to be similar to that reported by Greeley using arterial blood sample in a similar age group $\left(2.9 \mathrm{~L} \cdot \mathrm{kg}^{-1}\right.$ vs $\left.2.7 \mathrm{~L} \cdot \mathrm{kg}^{-1}\right){ }^{6}$ We do not think that the big difference in clearance between our study and the one reported in adolescents can be explained by different blood sampling sites.

In our study the limit of quantitation was achieved earlier ( $t_{\text {end }}$ Table II) than in Bovill's study (480 min). ${ }^{12}$ However, we believe that in our study the clearance was not overestimated for the following reasons. First, it can be seen in the Figure that sufentanil enters its postdistribution phase one hour after its administration and remains linear for the remaining time. This was consistent in the four patients in which sufentanil plasma concentrations were higher than $50 \mathrm{pg} \cdot \mathrm{ml}^{-1}$ after seven hours. In these patients, the estimated half-life was greater than that observed when sampling duration was shorter but the clearance and Vdss were not changed proportionally. Second, the area under the curve extrapolated to infinity ( $\mathrm{AUC}_{\mathrm{e}_{\text {end-o }}}$ ) represented, in all cases, less than $20 \%$ of the total area under the curve (range 6.3-19.6\%) (Table II), the sole exception being subject \#2, who had a $60 \mathrm{~min}$ sampling duration. Therefore, the limit of quantitation was not reached before at least three or four elimination halflives were measured.

The greater clearance in children could be explained by a greater hepatic blood flow and metabolism. The clearance of very lipophilic substances with a high extraction ratio such as sufentanil is highly dependent of the hepatic blood flow. ${ }^{16}$ In children, the liver represents 4 to $5 \%$ of the total body weight compared with $2 \%$ in the adult. ${ }^{17}$ Although no precise data on this subject were found in the literature, it seems logical that the child's hepatic blood flow according to body weight $\left(\mathrm{ml} \cdot \mathrm{kg}^{-1} \cdot \mathrm{min}^{-1}\right)$ would be superior to that of the adult. The metabolism of sufentanil is mainly by $\mathrm{O}$-demethylation and $\mathrm{N}$-dealkylation. In the child, the enzymatic activity of certain isoenzymes of the cytochrome P-450 system is increased. This has been demonstrated for numerous substances. For example the clearance of theophylline decreases from 1.7 to 0.9 and 0.6 $\mathrm{ml} \cdot \mathrm{kg}^{-1} \cdot \mathrm{min}^{-1}$ in children, adolescents and adults respectively. ${ }^{18-20} \mathrm{~A}$ greater clearance of sufentanil in children suggests that they require relatively greater maintenance doses than adults. Moreover, it would be theoretically possible to use a greater dose of sufentanil for surgery of short duration. According to Glenski, a dose greater than $0.5 \mu \mathrm{g} \cdot \mathrm{kg}^{-1}$ for surgery of short duration increases the risk of vomiting and respiratory depression. ${ }^{3}$ This study showed minor respiratory effects since the mean $\mathrm{PCO}_{2}$ in our patients after tracheal extubation was elevated $(47.6 \pm$ $7.8 \mathrm{mmHg}$ ), and no patients required naloxone. Only one patient, who had a cholecystectomy, vomited in the recovery room.

Our clearance results differed substantially from those described by Greeley et al. for a similar age group ( $30.5 \pm$ $8.8 \mathrm{ml} \cdot \mathrm{kg}^{-1} \cdot \mathrm{min}^{-1}$. vs $16.9 \pm 2.2 \mathrm{ml} \cdot \mathrm{kg}^{-1} \cdot \mathrm{min}^{-1}$ ) (Table III). ${ }^{6}$ The use of halothane by these authors may account, in part, for the difference, because hepatic blood flow is decreased by halothane and increased by isoflurane. ${ }^{21}$ Tissue uptake of a very lipid soluble substance such as sufentanil is limited by tissue blood flow. ${ }^{14,16}$ It is possible, therefore, that a decrease in hepatic blood flow and thus hepatic extraction by halothane decreases the 
metabolism of sufentanil and increases its elimination halflife. Halothane may also diminish the activity of cytochrome P-450 under certain circumstances. ${ }^{22,23}$ Nevertheless, considering the brief use of halothane in the Greeley $e t$ al. study and the low concentrations of isoflurane used in ours, it seems unlikely that the difference in anaesthesia technique is sufficient to account for the large differences in clearance. Another explanation may be in population, since all the patients studied by Greeley had cardiopathy. Cardiac insufficiency may decrease the hepatic blood flow which in turn will diminish the clearance of substances with a high extraction ratio as has been demonstrated for lidocaine. ${ }^{24}$ Furthermore, cardiac insufficiency may also reduce the activity of cytochrome $\mathrm{P}-450 .{ }^{25}$ It is probable that the clearance of sufentanil is reduced in children with cardiopathy.

In conclusion, the clearance of sufentanil in normal children between two and eight years of age was found to be twice as rapid as that previously described in adults. The Vdss was greater than in adults when expressed as a function of body weight and was similar to that of adults when expressed as a function of body surface area.

\section{Acknowledgements}

The authors wish to thank Dr. Susanna Furfaro and Mrs. Louise Lortie for their editorial assistance, and all the members of the Department of Anaesthesia at Ste-Justine Hospital for their collaboration and support.

\section{References}

1 Hickey $P R$, Hansen $D D$. Fentanyl and sufentanil-oxygenpancuronium anesthesia for cardiac surgery in children. Anesth Analg 1984; 63: 117-24.

2 Moore RA, Yang SS, McNicholas KW, Gallagher JD. Clark $D L$. Hemodynamic and anesthetic effects of sufentanil as the sole anesthetic for pediatric cardiovascular surgery. Ancsthesiology 1985; 62: 725-31.

3 Glenski JA, Friesen RH, Lane GA, Young S, Glascock J. Low-dose sufentanil as a supplement to halothane $/ \mathrm{N}_{2} \mathrm{O}$ anesthesia in infants and children. Can J Anacsth 1988 35: 379-84.

4 Vercauteren $M$, Boeckx E. Hangegreefs $G$, Noorduin $H$, Vanden Bussche $G$. Intranasal sufentanil for pre-operative sedation. Anaesthesia 1988; 43: 270-3.

5 Henderson JM, Brodsky DA, Fisher DM, Bretl Cm, Hertzka RE. Pre-induction of anesthesia in pediatric patients with nasally administered sufentanil. Anesthesiology 1988; 68: 67I-5.

6 Greeley WJ, De Bruijn NP, Davis DP. Sufentanil pharmacokinetics in pediatric cardiovascular patients. Anesth Analg 1987; 66: 1067-72.
7 Davis PJ, Cook DR, Stiller RL, Davin-Robinson KA. Pharmacodynamics and pharmacokinetics of high-dosc sufentanil in infants and children undergoing cardiac surgery. Anesth Analg 1987; 66: 203-8.

8 Greeley WJ, De Bruijn NP. Changes in sufentanil pharmacokinetics within the neonatal period. Anesth Analg 1988; 67: 86-90.

9 Koren G, Goresky G, Crean P, Klein J, MacLeod SM. Unexpected alterations in fentanyl pharmacokinetics in children undergoing cardiac surgery: age related or disease related? Dev Pharmacol Ther 1986; 9: 183-91.

10 Michiels M, Hendriks R, Heykants J. Radioimmunoassay of the new opiate analgesics alfentanil and sufentanil. Preliminary pharmacokinetic profile in man. J Pharm Pharmacol 1983; 35: 86-93.

11 Gibaldi $M$, Perrier D. Pharmacokinctics. New York, Marcel Dekker, 1982, pp 409-17.

12 Bovill JG, Sebel PS, Blackburn CL, Oei-Lim V. Heykants $J J$. The pharmacokinetics of sufentanil in surgical patients. Anesthesiology 1984; 61: 502-6.

13 Davis PJ, Stiller RL, Cook DR, Brandom BW, Davin-Robinson $K A$. Pharmacokinetics of sufentanil in adolescent patients with chronic renal failure. Anesth Analg 1988; 67: 268-71.

14 Davis PJ, Cook DR. Clinical pharmacokinetics of the newer intravenous anaesthetic agents. Clin Pharmacol 1986; 11: 18-35.

15 Chiou WL. The phenomenon and rationalc of marked dependance of drug concentration on blood sampling site: implications in pharmacokinetics, pharmacodynamics. toxicology and therapeutics (Part II). Clin Pharmacokinet 1989; 17: 275-90.

16 Nies AS, Shand DG, Wilkinson GR. Altered hepatic blood flow and drug disposition. Clin Pharmacokinet 1976; I: 135-55.

17 Balistreri WF. Development of hepatic and biliary structure and function. In: Behrman RE, Vaughan VC (Eds.) Nelson Textbook of Pediatrics, 13th ed., Philadelphia: WB Saunders Cie., 1987: 821-4.

18 Loughan PM, Sitar DS, Oglivie RI, Eisen A, Fox F, Neims $A H$. Pharmacokinetic analysis of the disposition of intravenous theophylline in the young children. J Pediatr 1976; 88: 874-9.

19 Gichansky E. Weinberger $M$. Relationship of theophylline clearance to oral dosage in children with chronic asthma. J Pediatr 1977; 91: 655-60.

20 Hendeles $L$, Weinberger $M$, Bighley $L$. Disposition of theophylline after a single intravenous infusion of aminophylline. Am J Resp Dis 1978; 118: 97-103.

21 Gelman $S$, Fowler $K C$ and Smith LR. Liver circulation and function during isoflurane and halothane anesthesia. Anesthesiology 1984; 61: 726-30. 
22 Karlin $J M$, Kunt $H$. Acute diphenylhydantoin intoxication following halothane anesthesia. J Pediatr 1970; 76: $941-4$.

23 White $P F$, Johnstone $P R$, Pudwill $C R$. Interaction of ketamine and halothane in rats. Anesthesiology 1975; 42: 179-86.

24 Stenson RE, Constantino RI, Harrison DC. Interrelationship of hepatic blood flow, cardiac output and blood levels of lidocaine in man. Circulation 1971; 43: 205-11.

25 Hepper GW, Vesell ES, Tantum KR. Reduced drug elimination in congestive heart failure: studies using aminopyrine as a model drug. Am J Med 1978; 65: 271-6. 